Sir - The possibility that the children of individuals affected by the teratogen thalidomide may inherit similar abnormalities has again been raised. Huang and $\mathrm{McBride}^{1}$ have presented data that purport to show that thalidomide is capable of binding covalently to the DNA of rat embryos whose mothers were treated with the chemical on day 12 of pregnancy. These data were interpreted by the authors to support an earlier claim by McBride that thalidomide represents the first known human germ-cell mutagen ${ }^{2}$.

The latest paper was preceded by an editorial ${ }^{3}$ in which it was stated that "the paper contains so many inadequacies that it is not possible to draw any conclusions.... The data do not shed any light on the possible mode of the teratogenic action of thalidomide." It appears that the editors of the journal decided to publish the paper with the aim of formally discrediting the work. In the circumstances, this unprecedented stratagem seems to be justified. Nonetheless, the editorial warnings have been largely ignored and the sparse experimental data presented have been transmuted by a number of newspapers and magazines to the alleged demonstration of a specific interaction between thalidomide and the DNA of rat sperm and ova.

Given this accelerating distortion of science, and the human distress it may cause, it is appropriate to note that the definitive study of the mutagenic potential of thalidomide mentioned earlier ${ }^{4}$ is now in press with Mutation Research ${ }^{5}$. Leading investigators from five centres in the United Kingdom, the United States and the Netherlands have conducted exhaustive tests on this chemical using a wide range of in vitro and in vivo mutagenicity assays. The range of tests extends from cytogenetic studies conducted using human lymphocytes and fetal rabbit S9 mix to the first bone marrow micronucleus assay conducted in the rabbit. Uniformly negative results were obtained in each assay, and it is concluded that thalidomide is not a mutagen.

Any further discussion of the transmission to the next generation of birth deformities induced by thalidomide will therefore represent uninformed speculation. Prepublication copies of the Mutation Research paper $^{5}$ are available for study by competent authorities.

John Ashby

Zeneca Central Toxicology Laboratory, Alderley Park,

Cheshire SK10 4TJ, UK

1. Huang, P.H.T. \& McBride, W.G. Terat. Carcin. Mut. 17, 1-6
(1997).
2. McBride, W.G. Br. Med. J. 308, 1035-1036 (1994).
3. Neubert, D. Terat. Carcin. Mut. 17, i (1997).
4. Ashby, J. \& Tinwell, H. Nature 375, 453 (1995).
5. Ashby, J. et al. Mutat. Res. 380, (in the press).

\section{Contaminated water}

Sir-Some points in your welcome coverage of the radioactive waste water leak from the Chalk River Laboratories of Atomic Energy of Canada Limited (AECL) into the Ottawa River need clarification (Nature 387, 747; 1997).

For example, the statement that the "Canadian government has ordered a halt to the disposal of liquid waste from Atomic Energy of Canada's main nuclear research site" is only partly correct. Yes, discharge of liquid waste to the liquid dispersal area was suspended. But large quantities of liquid wastes are still routinely discharged directly into the Ottawa River through three separate sewer systems. One of them, the process sewer, has an outfall 114 metres from the shore at a depth of 17 metres. It carries waste from the NRU reactor and the heavy-water upgrading facility. Wastes released from this outfall in 1995 included 20,000 GBq of tritium, 4,200 GBq of sodium-24, 72 GBq of caesium-137 and 0.4 $\mathrm{GBq}$ of various plutonium isotopes.

The fact that the total amount of tritium released in the recently reported leaks ( 570 GBq per month) corresponded to only 0.01 per cent of the legally permissible limits on releases from the site does not allay concerns of downstream residents, nor do we think it should. What it does do is to call into question radionuclide release limits for the Chalk River site.

These limits, calculated in 1982 by a staff member at the Chalk River facility, are several hundred times higher than those for the four CANDU reactors at the Pickering
A generating station. Not only are the permissible releases very high (for example, $3.5 \times 10^{8} \mathrm{GBq}$ of tritium per year), but they are applied to each individual isotope and point of release. In all, some 60 -odd radionuclides may be released into the Ottawa River in amounts totalling more than 40 billion billion $\mathrm{Bq}$ each year.

The point that "government action seems to have been prompted by public concern rather than evidence of a clear danger" is interesting. Some would argue that discharging large quantities of carcinogenic, mutagenic radionuclides into a drinking-water source used by millions of Canadians is inevitably dangerous.

It is true, however, that studies quantifying the damage in populations downstream have not yet been done. Limited environmental data are available that show contamination of local beaches, fish and drinking-water supplies for communities as far downstream as Ottawa. Perhaps you will carry a subsequent chapter in this story some time in the future.

Lynn Jones

(President)

Concerned Citizens of Renfrew County,

PO Box 981, Pembroke,

Ontario K8A 7M5, Canada

\section{No politics, please}

Sir - Despite the good intentions in your leading article "Small symbols of peace", it was disconcerting that it brought in undue political views by terming Binyamin Netanyahu's policies “expansionist”
(Nature 386, 525; 1997). The implication was, of course, that the prime minister of Israel was solely to blame for the impasse in the peace negotiations with the Palestinians.

Netanyahu has not expanded existing settlements, nor has he created even one additional settlement over the number he inherited from the previous government. Your statement, therefore, creates a false impression that impedes rather than helps the complicated efforts to create an acceptable atmosphere for furthering the peace efforts.

\section{David Gershon}

Faculty of Biology,

Technion-Israel Institute of Technology,

Technion City,

Haifa 32000, Israel

\section{As others see us}

Sir - John Hodgson's observations of the distance-dependent perception of scientists are most accurate and bear witness to thorough research into the behaviour of this species (Nature 388, 420; 1997). But he omitted one crucial example:

I have just written a nice satirical piece about scientists

You are always so ironical

He is just a cynical old b...

Michael Groß

Oxford Centre for Molecular Sciences,

New Chemistry Laboratory,

South Parks Road,

Oxford OX1 3QT, UK

e-mail:mgross@bioch.ox.ac.uk 